\title{
Comparison of the Properties of Halloumi Cheese Made from Goat Milk, Cow Milk and Their Mixture
}

\author{
N. B. Elgaml, M.A.M. Moussa and A. E. Saleh \\ Dairy Research Department, Animal Production Research Institute, Agriculture \\ Research Centre, Ministry of Agriculture, Cairo, Egypt
}

\begin{abstract}
THE PURPOSE of this study is to compare the physico-chemical, microbiological and rheological properties of among Halloumi cheese made from $100 \%$ goat's milk (T1), $50 \%$ cow's milk and 50\% goat's milk (T2), $75 \%$ cow's milk and $25 \%$ goat's milk (T3) and $100 \%$ cow's milk (T4), during the storage period at $5^{\circ} \mathrm{C}$ in brine solution ( $12 \%$ sodium chloride) . The goat cheese (T1) gave the highest value in the moisture content, the total volatile fatty acids (TVFA), the ash, the highest level of Halloumi cheese, and 50\% cow's milk (T2) was the lowest. There were also insignificant differences $(p<0.05)$ in water soluble nitrogen (WSN) and fat / total solid, in the four treatments of cheese. T3 was the highest in fat ratio, non protein nitrogen (NPN), salt, total solid, salt / moisture content. Total number of bacteria for all fresh samples were significantly $(\mathrm{P}<0.05)$. The coliform and E. coli bacteria were less than $30(\mathrm{cfu} / \mathrm{g})$ and were present in the four treatments of cheese. None of them showed Staph. aureus during the months of storage. The molds\& yeasts were found in small numbers by 13 to $16(\mathrm{cfu} / \mathrm{g})$ in the Halloumi cheese ( 3 months). The rheological characteristics of the Halloumi cheese (T4) were less in consistent and the better taste comparing with the other treatments.
\end{abstract}

Keywords: Halloumi cheese, Goat's milk, Cow milk, Cheese evaluation, TVFA, Protein hydrolysis, Keeping quality.

\section{Introduction}

Halloumi is the traditional cheese of Cyprus; its unique characteristics as a product for raw consumption or cooking (primarily grilled or fried) have made it popular in the Middle East, European Union, Australia and USA. For many years, it has been produced locally from raw ovine milk or mixtures of raw ovine and caprine milk. A similar product under the same name in Syria and Lebanon is made as semi hard to hard cheese made mainly from sheep milk, goat milk, cow milk or a mixture of them in various ratios (Davies, 1970), The manufacture of Halloumi cheese has been described by Anifantakis and Kaminarides (1982).

Traditionally ovine and caprine milk, or a mixture of the two in various ratios, were used for the manufacture of Halloumi cheese, but nowadays the large dairies use bovine milk almost exclusively. This recent transition towards bovine milk has resulted from the low levels of production of ovine and caprine milk, but it has had an impact on the sensory quality of the cheese.

During maturation, Halloumi cheese changes markedly in taste and texture and the cheese becomes hard, salty and moderately acidic. Although the microbiology and biochemistry of these changes are poorly understood, the sensory properties of mature Halloumi are much appreciated by connoisseurs. It is a semi-hard rindless cheese preserved in brine (Anifantakis and Kaminarides, 1984).

This fresh product has a characteristic aroma, its texture is elastic and compact with no holes and it is easily sliced. It is popular with consumers and large quantities of Halloumi are sold immediately after production. Halloumi cheese made from cow's milk is more yellowish in color and lacks the sensory characteristics of the Halloumi cheese that is made from sheep's milk (Kaminarides et al., 2000). The yeasts isolated from the commercial 
samples of fresh and mature Halloumi cheeses did not have any adverse effects on the flavour or produce visible defects. A new lactobacillus strain has been isolated from mature Halloumi cheese made in Cyprus, which suggests that this organism is resistant to high salt concentrations and low pH (Lawson et al., 2001).

Sharri cheese is traditionally produced from ovine, bovine and mixed milk and classified as a hard and /or semi hard cheese with high salt content . The results show significant decrease in all microbiological parameters starting from total viable count, psychrophile and total LAB by increasing the brine salinity during a processing until a final product. Cheese stored on $6 \%$ and $22^{\circ} \mathrm{C}$ had higher scores from the panelists. The results show that, controlling the raw milk quality in microbiological aspects before processing is necessary. At the same time for making Sharri cheese the recommended concentration of brine solution is $6-9 \%$ and $22^{\circ} \mathrm{C}$ of storage condition. By using this condition we will have under control total viable counts, no significant changes between raw milk and final product of LAB diversity and no negative effects in human health (Mergim Mestani, 2017).

The present study is to establish the relationships between the major constituents that influence the yield and composition of Halloumi cheese made from different milks. The major of milk production in Egypt was cows' milk, while the goat milk is not available and more expensive. So, the aim of this study was to compare the chemical, microbiological and sensory characteristics of Halloumi cheese made from goat milk, cow milk, and mixture of them, which were used for the manufacture of Halloumi cheese in Egypt.

\section{Materials and Methods}

\section{Milk}

Whole fresh goat's and cow's milk or mixtures of these milks were obtained from herds of Sakha Animal Production Research Station, Animal Production Research Institute, Agriculture Research Center, Ministry of Agriculture, Egypt.

\section{Rennet}

Standard liquid rennet was used in the manufacture of cheese in these stations .

\section{Cheese making}

Forty litters of fresh milk were used to make Halloumi cheese for all these treatments; $100 \%$ goat's milk (T1), 50\% cow's milk and 50\% goat's milk (T2), $75 \%$ cow's milk and $25 \%$ goat's milk (T3) and $100 \%$ cow's milk (T4).The coagulation milk by rennet at $35^{\circ} \mathrm{c}$ for $45 \mathrm{~min}$ after that the curd was cut to $1 \mathrm{~cm}^{3}$ then coagulum was precipitated for $10 \mathrm{~min}$, the curd was pressed of 550 pa for $1 \mathrm{hr}$, after that was cut into blocks $(10 \times 10 \times 30 \mathrm{~cm})$ and put the blocks in hot whey at $90^{\circ} \mathrm{C}-95^{\circ} \mathrm{C}$ for $1 \mathrm{hr}$, then drained, cooled and dry salt at $3 \% \mathrm{w} / \mathrm{w}$ was added and sprinkled with dry peppermint leaves, in final storage the cheese was put in brine solution $(12 \% \mathrm{NaCl})$ as described by Anifantakis and Kaminarides (1982).

\section{Experimental planning and sampling}

The resultants of Halloumi cheese samples were taken at $0,1,2$ and 3 months to evaluate physicochemical, microbiological and organoleptic properties. The sample from each treatment was divided into three portions as follows:

*The first was used for chemical analysis.

*The second was ground under sterilized conditions and immediately used for microbiological examinations.

*The third was used for the organoleptical and rheological properties.

\section{Cheese yield}

Cheese yield $($ fresh $)=\mathrm{kg}$ of cheese $/ \mathrm{kg}$ of milk $\times 100$.

\section{Physicochemical analyses \\ Milk and cheese samples}

The milk used for cheese making was weighed, and analyzed for fat , protein, lactose, solid not fat (SNF), and total solids(TS) by milko scan, model 133B. Also, analyzed Halloumi cheese samples as follows: total solid, total protein, non protein nitrogen (NPN), water soluble nitrogen (WSN), ash, fat, and titratable acidity were determined according to standard methods of A.O.A.C. (2000). The $\mathrm{pH}$ values were measured in milk and Halloumi cheese samples using $\mathrm{pH}$ meter (Hanna HI Instrument model 8021 Germany), while, total volatile fatty acids (TFVA) were determined as given by Kosikowski (1982).

\section{Textural profile analysis}

Textural profile of Halloumi cheese was measured at $23^{\circ} \mathrm{C}$ as described by Kosikowski (1982). Using an Instron Universal Tasting 
Machin model 1195, StableMicro system. (SMS) LTD., Godalming, UK, loaded with Dimension software SMS program. Likwise, Penetration Microbiological Estimation

Total plate counts of bacteria, coliform, E. coli, Staph. aureus, and molds\& yeasts were determined according to the method described by Houghtby et al. (1992).

\section{Sensory Evaluation}

The organoleptic properties of the resultant Halloumi cheese were assessed by a test panel of 10 persons according to the scheme described by Nelson and Trout (1981).

\section{Statistical Analysis}

Results were statistically analyzed by one way complete design to study the effect of treatment using SAS (2004). However, the significant differences among means were tested using Duncan's Multiple Range Test (Duncan, 1955).

\section{Results and Discussion}

Physio-chemical properties of the four treatments of milk

The physio-chemical properties of the all treatments of milk used for production of Halloumi cheese are given (Table 1). Goat milk (T1) had the highest content of total solids, fat, protein, ash, casein, and acidity, whereas (T4) cow milk had the lowest values of total solids, fat, protein, except for $\mathrm{pH}$ value and casein $\backslash$ fat ratios were highest. Total solids, fat, SNF, ash and acidity were significant higher $(\mathrm{P}<0.05)$ in $\mathrm{T} 3$ than in T2.The results in this study was agreed with those reported by Anifantakis and komimres (1982).

\section{Cheese yield}

The average cheese yield of the all treatments of Halloumi cheese are illustrated in Fig. 1 produced from T1, T2, T3 and T4 after 1 day (fresh) was $12.5,11.0,12.0$, and 10.0\%, respectively. The highest value of cheese yield fromT1, T3, T4 and $\mathrm{T} 2$. The results can be attributed to differences in chemical composition of the milk used for making Halloumi cheese (Table 1).

TABLE 1. Physio-chemical properties of the four treatments of milk for production Halloumi cheese

\begin{tabular}{|c|c|c|c|c|}
\hline \multirow[b]{2}{*}{ Physicochemical } & \multicolumn{4}{|l|}{ Treatment* } \\
\hline & $\begin{array}{l}\text { T1 } \\
* 100 \text { Goat milk }\end{array}$ & $\begin{array}{l}\text { T2 } \\
\text { 50Cow milk }\end{array}$ & $\begin{array}{l}\text { T3 } \\
\text { 75Cow milk }\end{array}$ & $\begin{array}{l}\text { T4 } \\
\text { 100Cow milk }\end{array}$ \\
\hline Total solids (\%) & $12.2 \pm 0.05 \mathrm{a}$ & $11.9 \pm 0.07 \mathrm{~b}$ & $11.7 \pm 0.02 \mathrm{c}$ & $11.5 \pm 0.07 \mathrm{~d}$ \\
\hline Fat $(\%)$ & $4.21 \pm 0.02 \mathrm{a}$ & $4.03 \pm 0.06 \mathrm{~b}$ & $3.93 \pm 0.02 \mathrm{c}$ & $3.8 \pm 0.04 \mathrm{~d}$ \\
\hline Total protein $(\%)$ & $2.91 \pm 0.02 \mathrm{a}$ & $2.65 \pm 0.05 b$ & $2.61 \pm 0.02 b$ & $2.58 \pm 0.03 \mathrm{c}$ \\
\hline Casein $(\%)$ & $2.32 \pm 0.02 \mathrm{a}$ & $2.12 \pm 0.04 \mathrm{~b}$ & $2.12 \pm 0.02 b$ & $2.06 \pm 0.02 \mathrm{c}$ \\
\hline Casein/fat $(\%)$ & $52.85 \pm 0.41 \mathrm{~b}$ & $52.79 \pm 0.60 \mathrm{~b}$ & $54.07 \pm 0.34 \mathrm{a}$ & $54.35 \pm 0.24 \mathrm{a}$ \\
\hline Casein /protein $(\%)$ & $80 \pm 0.14 \mathrm{a}$ & $80.0 \pm 0.00 \mathrm{a}$ & $79.9 \pm 0.08 \mathrm{a}$ & $80.1 \pm 0.13 \mathrm{a}$ \\
\hline S.N.F $(\%)$ & $7.8 \pm 0.03 b$ & $7.9 \pm 0.01 \mathrm{a}$ & $7.8 \pm 0.01 \mathrm{~b}$ & $7.7 \pm 0.01 \mathrm{c}$ \\
\hline Lactose $(\%)$ & $4.24 \pm 0.02 b$ & $4.41 \pm 0.02 \mathrm{a}$ & $4.48 \pm 0.01 \mathrm{a}$ & $4.41 \pm 0.05 \mathrm{a}$ \\
\hline Ash (\%) & $0.84 \pm 0.01 \mathrm{a}$ & $0.81 \pm 0.02 b$ & $0.68 \pm 0.02 \mathrm{c}$ & $0.73 \pm 0.02 \mathrm{~d}$ \\
\hline $\mathrm{pH}$ & $6.4 \pm 0.05 \mathrm{c}$ & $6.6 \pm 0.05 \mathrm{ab}$ & $6.5 \pm 0.01 \mathrm{~b}$ & $6.6 \pm 0.04 \mathrm{a}$ \\
\hline Acidity, as lactic acid (\%) & $0.19 \pm 0.01 \mathrm{a}$ & $0.18 \pm 0.01 \mathrm{a}$ & $0.19 \pm 0.01 \mathrm{~b}$ & $0.18 \pm 0.01 \mathrm{~b}$ \\
\hline
\end{tabular}

* T1:100\% goat's milk..T2: 50\% cow's milk with 50\% goat's milk, T3: $75 \%$ cow's milk with $25 \%$ goat's milk. T4:100\% cow's milk. ${ }^{\text {abcd }}$ Letters indicate significant differences between Halloumi cheese treatments. 


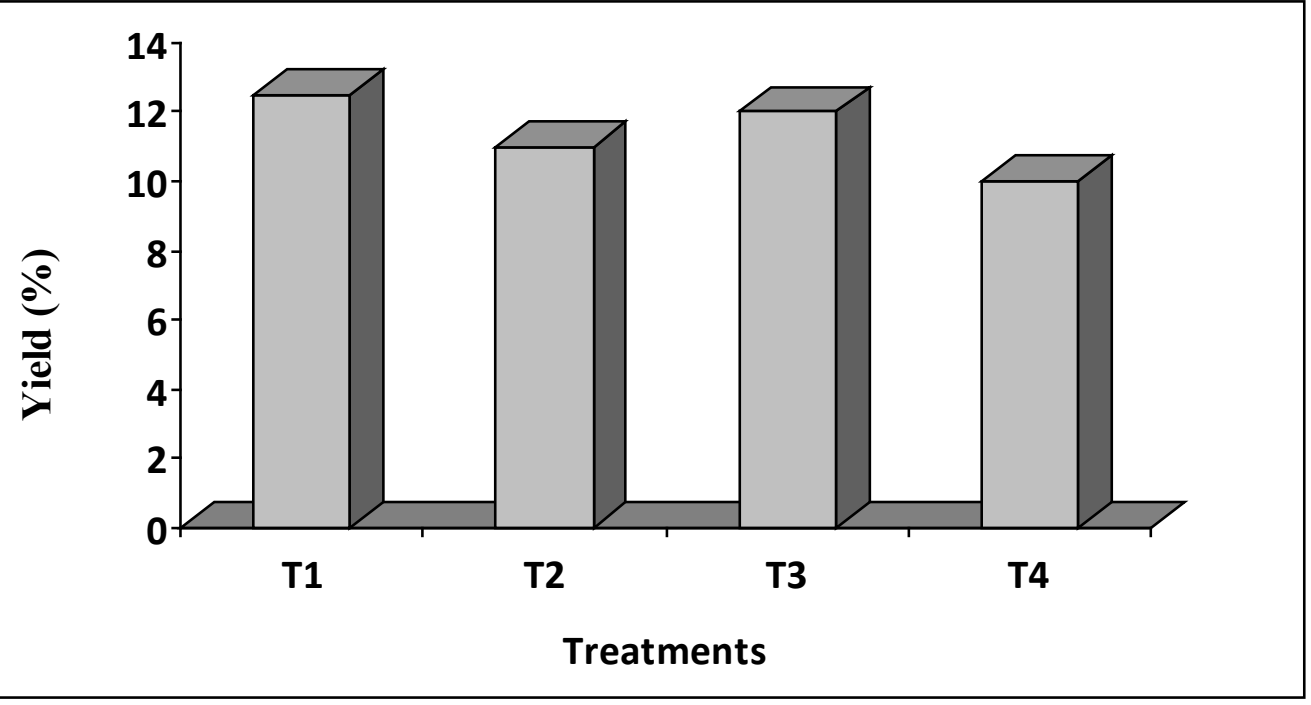

Fig. 1. The yield of Halloumi chasse made from four treatments of milk

\section{Physio-chemical properties of cheese}

The results of the chemical composition of all the experimental Halloumi cheese fresh and after 3 months are shown in Tables 2 and 3. Cheese from $\mathrm{T} 1$ and $\mathrm{T} 4$ had higher significant differences $(\mathrm{P}<0.05)$ in moisture content than treatments 2 and 3 , although, $\mathrm{T} 3$ was significantly lower $(\mathrm{P}<0.05)$ as compared to $\mathrm{T} 2$, moisture content, $\mathrm{pH}$, and ash, these results can be attributed to differences in chemical composition of the milk used for making Halloumi cheese (Table 1) the four treatments cheese did not show any significant differences $(\mathrm{P} \leq 0.05)$ in WSN content and Fat/ DM. However, the effect of F/DM on meltability, which was important factor for Halloumi, was greatly modified by reducing the $\mathrm{pH}$ of the cheese according to findings of Panayiota theophil and .(Andrew wilbey (2007

Treatment (T3) had a higher in fat, protein, NPN, salt, TS and salt in moisture this results is mainly attributed to the total protein of casein to fat present the highest moisture, and $\mathrm{pH}$ content was observed in cheese made from $100 \%$ cow milk (T4). The moisture contents of Halloumi cheese from all treatments were within the Egyptian Standards (1970) for semihard cheeses $(40-50 \%)$. Also, the obtained results of the produced Halloumi cheese were in agreement with that obtained by Anifantakis and Kaminarides (1982). TVFA content were higher in cheese made from $100 \%$ goat milk (T1) at the period storage could be due to the high goat milk composition and increased fat content, the results

Egypt. J. Sus. Agric. Sci . 43, No.2 (2017) in Tables 2 and 3 showed the highest fat, protein, fat / Dm, salt, moisture content after 3 months in all treatments, although, WSN was not significant in period storage and all treatments, the average values of salt was among of $(2.75-4.56 \%)$ the difference in salt content of all treatments were mainly due to the variation in moisture content of Halloumi cheese, whereas the average value of salt was increased with period storage according to findings of Milci et al. (2005).

\section{Microbiological analysis}

The evaluation of bacteria counts when fresh and then after 3 months in Halloumi cheese samples are shown in Table 4. The total plate count of bacteria for all fresh samples is significantly $(\mathrm{P}<0.05)$. Higher values were obtained for cheese made from raw goat milk than other treatments cheese, on the other hand the total count decreased until the end of cold storage period ( 3 months) were $4.3,3.6,3.1$, and $3.1 \times 10^{3}(\mathrm{cfu} / \mathrm{g})$ for cheese made from $\mathrm{T} 1, \mathrm{~T} 2, \mathrm{~T} 3$ and $\mathrm{T} 4$, respectively .These results were in agreement with Milci et al. (2005). They reported that, the total aerobic bacteria counts decreased during the storage. The observed decrease in bacteria growth could be due to the decrease in the amount of remaining sugar (lactose) in cheese and resulting in fewer nutrients for their growth promotion. Nezhad et al. (2013) and Mergim Mestani (2017) found a significant decrease in all microbiological parameters starting from total viable count, psychrophile and total LAB by increasing the brine salinity during a processing until a final product. 
TABLE 2. Physio-chemical properties of Halloumi cheese made from different treatments of milk

\begin{tabular}{|c|c|c|c|c|c|c|}
\hline \multirow{2}{*}{ Component } & \multirow{2}{*}{$\begin{array}{c}\text { Storage } \\
\text { (months) at } \\
5^{\circ} \mathrm{C}\end{array}$} & \multicolumn{5}{|c|}{ *Treatment } \\
\hline & & T1 & $\mathbf{T 2}$ & T3 & T4 & $\operatorname{Mean} \pm \mathbf{s d}$ \\
\hline \multirow{5}{*}{ Moisture \% } & Fresh & $43.13 \pm 0.01$ & $43.15 \pm 0.04$ & $43.57 \pm 0.02$ & $43.40 \pm 0.1$ & $43.40 \pm .01 \mathrm{~A}$ \\
\hline & 1 & $42.49 \pm 0.01$ & $42.26 \pm 0.02$ & $41.98 \pm 0.01$ & $42.43 \pm 0.01$ & $42.3 \pm .02 \mathrm{~B}$ \\
\hline & 2 & $42.40 \pm 0.04$ & $42.17 \pm 0.05$ & $41.81 \pm 0.04$ & $42.24 \pm .03$ & $42.29 \pm .04 \mathrm{C}$ \\
\hline & 3 & $41.52 \pm 0.05$ & $41.49 \pm 0.01$ & $41.49 \pm 0.01$ & $41.46 \pm .01$ & $41.49 \pm .02 \mathrm{D}$ \\
\hline & Mean \pm sd & $42.38 \pm .04 \mathrm{a}$ & 42.26.土.03b & $41.33 \pm .02 \mathrm{c}$ & $42.38 \pm .02 \mathrm{a}$ & \\
\hline \multirow{5}{*}{ WSN \% } & Fresh & $0.32 \pm 0.0$ & $0.32 \pm 0.0$ & $0.32 \pm 0.0$ & $0.33 \pm 0.0$ & $0.32 \mathrm{C}$ \\
\hline & 1 & $0.36 \pm 0.0$ & $0.38 \pm 0.0$ & $0.37 \pm 0.0$ & $0.38 \pm 0.0$ & $0.37 \mathrm{C}$ \\
\hline & 2 & $0.42 \pm 0.0$ & $0.43 \pm 0.0$ & $0.43 \pm 0.0$ & $0.43 \pm 0.0$ & $0.43 \mathrm{~B}$ \\
\hline & 3 & $0.47 \pm 0.0$ & $0.45 \pm 0.0$ & $0.46 \pm 0.0$ & $0.45 \pm .0 .0$ & $0.46 \mathrm{~A}$ \\
\hline & Mean \pm sd & $0.39 \pm 0.0$ & $0.39 \mathrm{a}$ & $0.39 \mathrm{a}$ & $0.39 \mathrm{a}$ & \\
\hline \multirow{5}{*}{ Salt $\%$} & Fresh & $2.92 \pm 0.01$ & $2.75 \pm 0.01$ & $3.15 \pm 0.01$ & $3.16 \pm 0.01$ & $2.99 \mathrm{D}$ \\
\hline & 1 & $3.16 \pm 0.01$ & $3.78 \pm 0.01$ & $4.17 \pm 0.01$ & $4.15 \pm 0.02$ & $3.82 \mathrm{C}$ \\
\hline & 2 & $3.85 \pm 0.03$ & $4.08 \pm 0.01$ & $4.55 \pm 0.01$ & $4.14 \pm 0.02$ & $4.15 \mathrm{~B}$ \\
\hline & 3 & $4.07 \pm 0.01$ & $4.11 \pm 0.02$ & $4.56 \pm 0.01$ & $4.15 \pm 0.02$ & $4.22 \mathrm{~A}$ \\
\hline & Mean \pm sd & $3.50 \mathrm{~d}$ & $3.68 \mathrm{c}$ & $4.11 \mathrm{a}$ & $3.90 \mathrm{~b}$ & \\
\hline \multirow{5}{*}{ TS $\%$} & Fresh & $56.87 \pm .04$ & $56.85 \pm 04$ & $56.43 \pm .03$ & $56.66 \pm .10$ & $57.12 \pm 0.79 \mathrm{D}$ \\
\hline & 1 & $57.51 \pm .03$ & $57.75 \pm 04$ & $58.05 \pm .04$ & $57.53 \pm .05$ & $57.72 \pm 0.04 \mathrm{C}$ \\
\hline & 2 & $57.6 \pm .03$ & $57.82 \pm .05$ & $58.19 \pm .04$ & $57.76 \pm .03$ & $57.84 \pm 0.04 \mathrm{~B}$ \\
\hline & 3 & $58.48 \pm .05$ & $58.55 \pm .04$ & $58.55 \pm .04$ & $58.54 \pm .04$ & $58.53 \pm 0.04 \mathrm{~A}$ \\
\hline & Mean \pm sd & $57.63 \pm 0.04 \mathrm{c}$ & $57.74 \pm 0.04 \mathrm{~b}$ & $58.06 \pm 0.04 \mathrm{a}$ & $57.62 \pm 0.05 \mathrm{c}$ & \\
\hline \multirow{5}{*}{$\mathrm{pH}$} & Fresh & $6.05 \pm 0.01$ & $6.02 \pm 0.05$ & $6.06 \pm 0.01$ & $6.08 \pm 0.01$ & $6.05 \pm 0.02 \mathrm{~A}$ \\
\hline & 1 & $5.45 \pm 0.01$ & $5.55 \pm 0.02$ & $5.55 \pm 0.01$ & $5.58 \pm 0.01$ & $5.53 \pm 0.01 \mathrm{~B}$ \\
\hline & 2 & $5.457 \pm 0.01$ & $5.46 \pm 0.01$ & $5.53 \pm 0.01$ & $5.55 \pm 0.01$ & $5.50 \pm 0.01 \mathrm{C}$ \\
\hline & 3 & $5.39 \pm 0.05$ & $5.43 \pm 0.01$ & $5.52 \pm 0.01$ & $5.53 \pm 0.01$ & $5.47 \pm 0.02 \mathrm{D}$ \\
\hline & Mean \pm sd & $.5 .59 \pm 0.02 \mathrm{~d}$ & $5.66 \pm 0.02 c$ & $.5 .67 \pm 0.01 \mathrm{~b}$ & $5.69 \pm 0.01 \mathrm{a}$ & \\
\hline
\end{tabular}
between storage periods of Halloumi cheese

Data presented in Table 4 showed that the total coliform and E.coli were detected in all samples in fresh cheese this might be due using raw milk without heat treatment, on the other hand, the total coliforms were not detected in all samples during the cold storage period. This may be due to increase the salt in cheese, storage in brine solution, and the role of lactic acid bacteria in preservation of the products and their metabolites on the growth coliforms. These results were in agreement with those of Panayiota theophil and Andrew wilbey (2007).

Data illustrated in Table 4 indicated that molds\&yeasts were absent in all cheese when fresh and after 3 months during storage period. The molds\&yeasts were detected in cheese during storage were 16, 14,15and 13 for the all treatments, respectively, the yeast in Halloumi cheese did not have any adverse effects on the flavour. According to Lawson et al. (2001) who found that the yeasts isolated from the commercial samples of fresh and mature Halloumi cheeses did not have any adverse effects on the flavour or produce visible defects, has been isolated from mature Halloumi cheese made in Cyprus, which suggests that this organism is resistant to high salt concentrations and low $\mathrm{pH}$.

The results in Table 4 showed that the Staph. aureus was not detected in all samples and also during period of storage. The decrease of microbial counts at the end of storage period could be due increasing the acidity during storage period. The bacteria growth has been isolated in high numbers from many traditional raw milk cheeses. The

Egypt. J. Sus. Agric. Sci . 43, No.2 (2017) 
TABLE 3. Physio-chemical properties of halloumi cheese made from different treatments of milk

\begin{tabular}{|c|c|c|c|c|c|c|}
\hline \multirow[t]{2}{*}{ Component } & \multirow{2}{*}{$\begin{array}{l}\text { Storage } \\
\text { (months) }\end{array}$} & \multicolumn{5}{|c|}{ *Treatment } \\
\hline & & T1 & T2 & T3 & T4 & $\operatorname{Mean} \pm \mathrm{sd}$ \\
\hline \multirow[t]{5}{*}{ Fat $\%$} & Fresh & $26.34 \pm 0.7$ & $25.30 \pm 0.10$ & $25.58 \pm 0.06$ & $25.10 \pm 0.7$ & $25.58 \mathrm{C}$ \\
\hline & 1 & $26.56 \pm 0.4$ & $26.20 \pm 0.3$ & $26.68 \pm 0.4$ & $25.27 \pm 0.4$ & $25.93 \mathrm{~B}$ \\
\hline & 2 & $26.63 \pm 0.4$ & $26.6 \pm 0.15$ & $26.87 \pm 0.2$ & $25.63 \pm 0.4$ & $25.93 \mathrm{~B}$ \\
\hline & 3 & $26.86 \pm 0.2$ & $26.70 \pm 0.15$ & $26.88 \pm 0.10$ & $25.87 \pm 0.2$ & $26.08 \mathrm{~A}$ \\
\hline & $\begin{array}{c}\text { Mean } \pm \text { sd } \\
\text { main } \pm \text { sd sd }\end{array}$ & $26.59 a$ & $26.2 \mathrm{a}$ & $26.05 a$ & $25.47 \mathrm{~b}$ & \\
\hline \multirow[t]{5}{*}{ Protein \% } & Fresh & $19.25 \pm 0.02$ & $19.01 \pm 0.03$ & $19.21 \pm 0.04$ & $18.95 \pm 0.04$ & 19.11D \\
\hline & 1 & $19.42 \pm 0.02$ & $19.22 \pm 0.03$ & $19.45 \pm 0.03$ & $19.18 \pm 0.04$ & $19.32 \mathrm{C}$ \\
\hline & 2 & $19.45 \pm 0.02$ & $19.31 \pm 0.03$ & $19.42 \pm 0.04$ & $19.21 \pm 0.05$ & $19.35 \mathrm{~B}$ \\
\hline & 3 & $19.48 \pm 0.03$ & $19.22 \pm 0.25$ & $19.59 \pm 0.04$ & $19.28 \pm 0.03$ & $19.39 \mathrm{~A}$ \\
\hline & Mean \pm sd sd & $19.40 \mathrm{a}$ & $19.19 b$ & $19.42 \mathrm{a}$ & $19.15 b$ & \\
\hline \multirow{5}{*}{$\begin{array}{l}\mathrm{NPN} \% \\
(\mathrm{NPN} \times 6.38)\end{array}$} & Fresh & $0.32 \pm 0.001$ & 0.320 .001 & $0.38 \pm 0.001$ & $0.38 \pm 0.001$ & $0.34 \mathrm{D}$ \\
\hline & 1 & $0.77 \pm 0.001$ & $0.83 \pm 0.001$ & $0.77 \pm 0.001$ & $0.77 \pm 0.001$ & $0.78 \mathrm{C}$ \\
\hline & 2 & $0.83 \pm 0.001$ & $0.83 \pm 0.001$ & $0.89 \pm 0.001$ & $0.89 \pm 0.001$ & $0.86 \mathrm{~B}$ \\
\hline & 3 & $0.83 \pm 0.001$ & $0.83 \pm 0.001$ & $1.02 \pm 0.03$ & $0.89 \pm 0.001$ & $0.88 \mathrm{~A}$ \\
\hline & Mean \pm sd sd & $0.70 \mathrm{~b}$ & $0.70 \mathrm{~b}$ & $0.77 \mathrm{a}$ & $0.73 \mathrm{ab}$ & \\
\hline \multirow[t]{5}{*}{ Fat/DM\% } & Fresh & $46.32 \pm 1.16$ & $44.79 \pm 0.19$ & $45.33 \pm 0.69$ & $44.30 \pm 0.79$ & $45.44 \pm 0.18 \mathrm{AA}$ \\
\hline & 1 & $46.18 \pm 0.71$ & $45.37 \pm 0.54$ & $45.96 \pm 0.59$ & $43.92 \pm 0.59$ & $44.92 \pm 0.18 \mathrm{~B}$ \\
\hline & 2 & $46.23 \pm 0.68$ & $46.00 \pm 0.29$ & $46.18 \pm 0.24$ & $44.44 \pm .03$ & $44.79 \pm 0.18 \mathrm{C}$ \\
\hline & 3 & $45.93 \pm 1.51$ & $45.60 \pm 0.25$ & $45.91 \pm 0.17$ & $44.19 \pm 0.47$ & $44.55 \pm 0.18 \mathrm{D}$ \\
\hline & Mean \pm sd sd & $46.14 \pm 1.1 \mathrm{a}$ & $45.44 \pm 1.1 \mathrm{a}$ & $45.84 \pm 1.2 \mathrm{a}$ & $44.21 \pm 1.3 \mathrm{~b}$ & \\
\hline \multirow[t]{5}{*}{ Salt $/$ moisture $\%$} & Fresh & $6.77 \pm 0.02$ & $6.47 \pm 0.03$ & $7.40 \pm 0.04$ & $7.17 \pm 0.02$ & $6.95 \pm 0.03 \mathrm{D}$ \\
\hline & 1 & $7.44 \pm 0.03$ & $8.94 \pm 0.02$ & $9.93 \pm 0.03$ & $9.78 \pm 0.02$ & $10.46 \pm 0.03 \mathrm{C}$ \\
\hline & 2 & $9.08 \pm 0.03$ & $9.68 \pm 0.03$ & $10.88 \pm 0.04$ & $9.80 \pm 0.02$ & $11.05 \pm 0.03 \mathrm{~B}$ \\
\hline & 3 & $9.80 \pm 0.02$ & $9.76 \pm 0.04$ & $10.99 \pm 0.04$ & $10.00 \pm 0.02$ & $11.24 \pm 0.03 \mathrm{~A}$ \\
\hline & Mean \pm sd sd & $8.27 \pm 0.03 \mathrm{~d}$ & $8.72 \pm 0.03 \mathrm{c}$ & $9.80 \pm 0.04 a$ & $9.18 \pm .02 \mathrm{~b}$ & \\
\hline \multirow[t]{5}{*}{ Ash $\%$} & Fresh & $5.49 \pm 0.02$ & $5.59 \pm 0.02$ & $5.15 \pm 0.04$ & $5.58 \pm 0.05$ & $4.94 \pm 0.04 \mathrm{D}$ \\
\hline & 1 & $5.88 \pm 0.01$ & $5.15 \pm 0.04$ & $5.52 \pm 0.06$ & $5.26 \pm 0.03$ & $5.45 \pm 0.04 \mathrm{C}$ \\
\hline & 2 & $6.12 \pm 0.04$ & $5.88= \pm 0.03$ & $6.25 \pm 0.01$ & $6.19 \pm 0.02$ & $6.16 \pm 0.03 \mathrm{~B}$ \\
\hline & 3 & $6.65 \pm 0.02$ & $6.54 \pm 0.02$ & $6.59 \pm 0.05$ & $6.42 \pm 0.07$ & $6.58 \pm 0.04 \mathrm{~A}$ \\
\hline & Mean \pm sd sd & $6.04 \pm 0.02 \mathrm{a}$ & $5.53 \pm 0.02 \mathrm{~d}$ & $5.88 \pm 0.04 b$ & $5.86 \pm 0.04 \mathrm{c}$ & \\
\hline \multirow{5}{*}{$\begin{array}{l}\text { TVFA } \\
(0.01 \mathrm{~N} \mathrm{NaOH})\end{array}$} & Fresh & $6.68 \pm 0.03$ & $3.49 \pm 0.05$ & $4.55 \pm 0.04$ & $4.35 \pm 0.04$ & $5.02 \pm 0.04 \mathrm{D}$ \\
\hline & 1 & $7.64 \pm 0.05$ & $6.50 \pm 0.04$ & $7.63 \pm 0.04$ & $6.95 \pm 0.04$ & $7.18 \pm 0.05 \mathrm{C}$ \\
\hline & 2 & $12.19 \pm 0.07$ & $10.64 \pm 0.05$ & $10.62 \pm 0.03$ & $10.20 \pm 0.05$ & $10.91 \pm 0.05 \mathrm{~B}$ \\
\hline & 3 & $14.68 \pm 0.03$ & $12.85 \pm 0.04$ & $12.52 \pm 0.04$ & $12.85 \pm 0.04$ & $13.23 \pm 0.04 \mathrm{~A}$ \\
\hline & Mean \pm sd sd & $10.30 \pm 0.02 \mathrm{a}$ & $8.37 \pm 0.05 \mathrm{~d}$ & $9.08 \pm 0.04 b$ & $8.59 \pm 0.04 c$ & \\
\hline
\end{tabular}

*See Table 1. abcd Letters indicate significant differences between Halloumi cheese treatments and ${ }^{\mathrm{ABCD}}$ Letters indicate significant differences between storage periods of Halloumi cheese

Egypt. J. Sus. Agric. Sci. 43, No.2 (2017) 
increase in salt content during maturation was related to the salt in the brine solution, these results are in agreement with Photis and Richard (2000).

\section{Rheological properties of cheese}

The results of rheological examination are presented in Table 5. The data showed that the hardness of cheese is described as the force required to penetrate the sample with the molar teeth (from soft to firm) (Lee et al.,1978). The cohesiveness, gumminess of cheese made from $100 \%$ cow milk (T4) were significantly $(\mathrm{P}<0.05)$ lower than in other cheese may be duo mainly to the lower fat and TS content (Table 1). The hardness and elasticity were lower during storage period; the fresh was 5.75, after three months was 5.33 but the gumminess and cohesiveness were increased with the storage period. Cheese made from (T1) 100\% goat milk was softer and showed significant higher value, the cheese made from (T2) 50\% cow milk exhibited a higher elasticity than others may be related to increase the ash content and TVFA content in cheese which influenced cheese elasticity in the different treatments of milk. Awad et al. (2002) reported that the difference among the cohesiveness values of cheese samples was originated from the difference in manufacturing technique and the raw material used. On the other hand, it was known that the storage time and the ripening period affected the cohesiveness value of cheese.

TABLE 4. Microbiological enumeration of Halloumi cheese made from different treatments of milk

\begin{tabular}{|l|c|c|c|c|c|}
\hline \multirow{2}{*}{$\begin{array}{c}\text { Microbiological } \\
\text { enumeration(cfu/g) }\end{array}$} & \multirow{2}{*}{$\begin{array}{c}\text { Storage } \\
\text { (months) }\end{array}$} & \multicolumn{4}{|c|}{ *Treatment } \\
\cline { 2 - 6 } & & T1 & T2 & T3 & T4 \\
\hline \multirow{2}{*}{ Total bacterial } & Fresh & $6.5 \times 10^{3}$ & $4.4 \times 10^{3}$ & $3.5 \times 10^{3}$ & $3.8 \times 10^{3}$ \\
\cline { 2 - 6 } & 3 & $4.3 \times 10^{3}$ & $3.6 \times 10^{3}$ & $3.1 \times 10^{3}$ & $3.1 \times 10^{3}$ \\
\hline \multirow{3}{*}{ Coliform } & Fresh & 30 & 30 & 20 & 20 \\
\cline { 2 - 6 } & 3 & ND & ND & ND & ND \\
\hline \multirow{2}{*}{ molds\& yeasts } & Fresh & ND & ND & ND & ND \\
\cline { 2 - 6 } & 3 & 16 & 14 & 15 & 13 \\
\hline \multirow{2}{*}{ E.coli } & Fresh & 20 & 20 & 15 & 15 \\
\cline { 2 - 6 } & 3 & ND & ND & ND & ND \\
\hline \multirow{2}{*}{ Staph. aureus } & Fresh & ND & ND & ND & ND \\
\cline { 2 - 6 } & 3 & ND & ND & ND & ND \\
\hline
\end{tabular}

*See Table 1 . 
TABLE 5. Rheological properties of halloumi cheese made from different treatments of milk

\begin{tabular}{|c|c|c|c|c|c|c|}
\hline \multirow{2}{*}{$\begin{array}{l}\text { Rheological } \\
\text { properties }\end{array}$} & \multirow{2}{*}{$\begin{array}{c}\text { Storage } \\
\text { (months) }\end{array}$} & \multicolumn{4}{|c|}{ *Treatment } & \multirow[b]{2}{*}{$\operatorname{Mean} \pm \mathrm{sd}$} \\
\hline & & T1 & $\mathbf{T 2}$ & T3 & T4 & \\
\hline \multirow{3}{*}{ Hardness (kg) } & Fresh & $6.46 \pm 0.07$ & $5.91 \pm 0.07$ & $5.55 \pm 0.07$ & $5.09 \pm 0.07$ & $5.75 \mathrm{~A}$ \\
\hline & 3 & $5.58 \pm 0.07$ & $5.36 \pm 0.07$ & $5.29 \pm 0.07$ & $5.14 \pm 0.07$ & $5.33 \mathrm{~B}$ \\
\hline & $\operatorname{Mean} \pm \mathrm{sd}$ & $6.02 \mathrm{a}$ & $5.61 b$ & $5.42 \mathrm{c}$ & $5.11 \mathrm{~d}$ & \\
\hline \multirow{3}{*}{ Elasticit y (mm) } & Fresh & $6.45 \pm 0.02$ & $7.90 \pm 0.02$ & $7.12 \pm 0.02$ & $6.98 \pm 0.02$ & 7.61A \\
\hline & 3 & $6.19 \pm 0.02$ & $7.42 \pm 0.02$ & $7.14 \pm 0.02$ & $6.89 \pm 0.02$ & $6.89 \mathrm{~B}$ \\
\hline & $\operatorname{Mean} \pm \mathrm{sd}$ & $6.32 d$ & $7.46 \mathrm{a}$ & $7.13 b$ & $6.91 \mathrm{c}$ & \\
\hline \multirow{3}{*}{$\begin{array}{l}\text { Cohesveness }(\mathrm{kg} \\
\times \mathrm{mm})\end{array}$} & Fresh & $0.23 \pm 0.01$ & $0.21 \pm 0.01$ & $0.17 \pm 0.01$ & $0.15 \pm 0.02$ & $0.19 \mathrm{~B}$ \\
\hline & 3 & $0.26 \pm 0.01$ & $0.23 \pm 0.01$ & $0.18 \pm 0.01$ & $017 \pm 0.02$ & $0.21 \mathrm{~A}$ \\
\hline & $\operatorname{Mean} \pm \mathrm{sd}$ & $0.24 \mathrm{a}$ & $0.22 b$ & $0.18 \mathrm{c}$ & $0.16 \mathrm{~d}$ & \\
\hline \multirow{3}{*}{ Gumminess (kg) } & Fresh & $1.48 \pm 0.02$ & $1.60 \pm 0.02$ & $1.62 \pm 0.02$ & $1.45 \pm 0.02$ & $1.54 \mathrm{~A}$ \\
\hline & 3 & $1.38 \pm 0.02$ & $1.6 \pm 0.02$ & $1.67 \pm 0.02$ & $1.33 \pm 0.02$ & $1.49 \mathrm{~B}$ \\
\hline & $\operatorname{Mean} \pm \mathrm{sd}$ & $1.43 \mathrm{c}$ & $1.6 \mathrm{~b}$ & $1.64 \mathrm{a}$ & $1.38 \mathrm{~d}$ & \\
\hline \multirow{3}{*}{$\begin{array}{l}\text { Chewiness }(\mathrm{kg} \times \\
\mathrm{mm})\end{array}$} & Fresh & $9.43 \pm 0.04$ & $10.52 \pm 0.04$ & $11.53 \pm 0.04$ & $10.26 \pm 0.04$ & $10.37 \mathrm{~B}$ \\
\hline & 3 & $9.88 \pm 0.04$ & $10.65 \pm 0.04$ & $11.64 \pm 0.04$ & $10.50 \pm 0.04$ & $10.60 \mathrm{~A}$ \\
\hline & $\operatorname{Mean} \pm \mathrm{sd}$ & $9.66 \mathrm{~d}$ & $10.59 b$ & $11.44 \mathrm{a}$ & $10.38 \mathrm{c}$ & \\
\hline
\end{tabular}

*See Table (1). ${ }^{\text {abcd }}$ Letters indicate significant differences between Halloumi cheese treatments and ${ }^{\mathrm{ABCD}}{ }^{\mathrm{Letters}}$ indicate significant differences between storage periods of Halloumi cheese

The rheological role of casein in cheese is to provide a continuous elastic framework for individual cheese granules. Cheese made from (T3) $75 \%$ cow milk had a significantly $(\mathrm{P}<0.05)$ greater gumminess and chewiness than the other cheese, the gumminess is the product of hardness, cohesiveness and chewiness of cheese made from (T3) was less hard but more cohesive than others, these results were in agreement with Kaminarides et al. (2000), Awad (2011) described the chewiness to be number of chews required to swallow a certain amount of sample. This property expressed mathematically as the product of gumminess; the same trend of those property include those factors that affect the curd moisture content (as temperature of coagulation and drain whey), cheese composition, $\mathrm{pH}$, casein and serum protein , $\mathrm{Ca}$ content, salt, fat and manufacturing of cheese for its many desirable functional and texture. In addition, increasing the moisture content might result in an increase in the level of free moisture in cheese, this increased the hardness.

\section{Organoleptical properties}

Results given in Table 6 showed the organoleptical evaluation of Halloumi cheese made in the four treatments. The total organoleptical of T4 and T3 were significantly higher $(\mathrm{P}<0.05)$ than $\mathrm{T} 2$, while $\mathrm{T} 1$ did not differ significantly within $\mathrm{T} 2$.The flavor in $\mathrm{T} 4$ was significant $(\mathrm{p}<0.05)$ higher $\mathrm{T} 2$, but no significant difference with $\mathrm{T} 1$ and $\mathrm{T} 3$, these results are in agreement with Anifantakis and Kaminarides (1984).

The flavor score value of all treatments of Halloumi cheese was gradually increased with the storage period progressed. The Halloumi cheese made from T4 recorded the highest score of flavor (86.91) followed T3 (83.56), T1 (83.17), and T2 (80.25). While, score texture and appearance in the all treatments cheese and at the progressed storage period not significant differences. It has been determined that Halloumi cheese can be stored successfully for 3 months (90 days) at $5^{\circ} \mathrm{C}$.

These results are in harmony with Stelios et al. (2015) who studied the propose Halloumi cheese curd cooking at $93-95 \mathrm{C}$ for $30 \mathrm{~min}$ as it not only reduces cheese making time and higher sensory scores for the end product cheese.

\section{Conclusion}

The results of the present study for manufactured Halloumi cheese from different types of milk showed that Halloumi cheese from (T3) are higher in fat, NPN, salt, TS, and salt in

Egypt. J. Sus. Agric. Sci. 43, No.2 (2017) 
moisture, and less hard but more cohesive than others. The assessment panel preference was for Halloumi cheese made from T4 and T3. Raw goat milk (T1) gave higher moisture content, TVFA, and ash and had the highest yield of Halloumi cheese but T2 was the lowest. Non significant differences in WSN content and fat/Dm content for all treatments. Total coliform and E. coli were detected in all samples in fresh cheese and the total coliform and E.coli Staph. aureus were not detected during the storage period, but the molds $\&$ yeasts were detected during storage which were $16,14,15$ and 13 for all treatments (T1, T2, T3 and $\mathrm{T} 4$, respectively).It is recommended to produce Halloumi cheese in Egypt from cow milk (T4) obtained high score in organoleptic properties.

TABLE 6. Organoleptic evaluation of halloumi cheese made from different treatments of milk

\begin{tabular}{|c|c|c|c|c|c|c|}
\hline \multirow{2}{*}{$\begin{array}{l}\text { Organoleptic } \\
\text { evaluation }\end{array}$} & \multirow{2}{*}{$\begin{array}{l}\text { Storage } \\
\text { (months) }\end{array}$} & \multicolumn{5}{|c|}{ *Treatment } \\
\hline & & T1 & $\mathbf{T} 2$ & T3 & T4 & $\operatorname{Mean} \pm$ sd \\
\hline \multirow{5}{*}{ Flavour(50) } & Fresh & $41.67 \pm 2.89$ & $35.00 \pm 8.66$ & $35.00 \pm 13.23$ & $43.33 \pm 2.89$ & $38.75 \pm 8.01 \mathrm{~B}$ \\
\hline & 1 & $42.33 \pm 4.04$ & $36.00 \pm 4.00$ & $41.00 \pm 1.00$ & $42.33 \pm 2.52$ & $41.17 \pm 3.04 \mathrm{AB}$ \\
\hline & 2 & $41.67 \pm 2.89$ & $39.33 \pm 8.15$ & $45.00 \pm 5.00$ & $46.67 \pm 2.89$ & $43.17 \pm 5.34 \mathrm{AB}$ \\
\hline & 3 & $45.00 \pm 0.00$ & $44.00 \pm 3.61$ & $44.67 \pm 4.51$ & $48.67 \pm 1.16$ & $45.58 \pm 5.71 \mathrm{~A}$ \\
\hline & Mean \pm sd & $42.67 \pm 2.84 \mathrm{ab}$ & $39.33 \pm 6.49 b$ & $41.42 \pm 7.61 \mathrm{ab}$ & $45.25 \pm 3.39 \mathrm{a}$ & \\
\hline \multirow{5}{*}{ Texture(40) } & Fresh & $35.00 \pm 5.00$ & $33.33 \pm 7.64$ & $35.00 \pm 5.00$ & $35.00 \pm 5.00$ & $34.58 \pm 4.98 \mathrm{~A}$ \\
\hline & 1 & $33.33 \pm 4.16$ & $32.00 \pm 3.46$ & $33.33 \pm 2.89$ & $34.67 \pm 2.51$ & $33.33 \pm 2.99 \mathrm{~A}$ \\
\hline & 2 & $31.67 \pm 2.89$ & $35.00 \pm 5.00$ & $35.00 \pm 5.00$ & $38.33 \pm 2.89$ & $35.00 \pm 4.26 \mathrm{~A}$ \\
\hline & 3 & $29.00 \pm 3.61$ & $29.67 \pm 7.51$ & $33.00 \pm 5.20$ & $35.00 \pm 0.00$ & $31.67 \pm 4.91 \mathrm{~A}$ \\
\hline & $\operatorname{Mean} \pm \mathrm{sd}$ & $32.25 \pm 4.12 \mathrm{a}$ & $32.50 \pm 5.63 \mathrm{a}$ & $34.08 \pm 4.01 \mathrm{a}$ & $35.75 \pm 3.11 \mathrm{a}$ & \\
\hline \multirow{5}{*}{ Appearance (10) } & Fresh & $8.67 \pm 0.58$ & $8.33 \pm 1.16$ & $8.33 \pm 2.08$ & $8.67 \pm 0.58$ & $8.50 \pm 1.09 \mathrm{~A}$ \\
\hline & 1 & $7.00 \pm 0.00$ & $8.33 \pm 1.16$ & $7.33 \pm 1.53$ & $8.00 \pm 0.00$ & $7.67 \pm 0.99 \mathrm{~A}$ \\
\hline & 2 & $8.33 \pm 1.53$ & $8.33 \pm 2.08$ & $8.67 \pm 0.58$ & $9.67 \pm 0.58$ & $8.75 \pm 1.42 \mathrm{~A}$ \\
\hline & 3 & $9.00 \pm 1.00$ & $8.67 \pm 0.58$ & $8.00 \pm 1.00$ & $6.33 \pm 2.52$ & $8.00 \pm 1.65 \mathrm{~A}$ \\
\hline & Mean \pm sd & $8.25 \pm 1.14 \mathrm{a}$ & $8.42 \pm 1.17 \mathrm{a}$ & $8.08 \pm 1.44 \mathrm{a}$ & $8.17 \pm 1.70 \mathrm{a}$ & \\
\hline \multirow{5}{*}{ Total (100) } & Fresh & 85.33 & 76.67 & 78.33 & 78.00 & $78.33 \mathrm{~A}$ \\
\hline & 1 & 82.67 & 79.33 & 81.67 & 85.00 & $81.67 \mathrm{~A}$ \\
\hline & 2 & 81.67 & 82.67 & 88.67 & 94.67 & $88.67 \mathrm{~A}$ \\
\hline & 3 & 83.00 & 82.33 & 85.67 & 90.00 & $85.67 \mathrm{~A}$ \\
\hline & $\operatorname{Mean} \pm \mathrm{sd}$ & $83.17 \mathrm{ab}$ & $80.25 b$ & $83.56 \mathrm{a}$ & $86.91 \mathrm{a}$ & \\
\hline
\end{tabular}

*See Table (1). ${ }^{\text {abcd }}$ Letters indicate significant differences between Halloumi cheese treatments and ${ }^{\mathrm{ABCD}}$ Letters indicate significant differences between storage periods of Halloumi cheese

\section{Reference}

Anifantakis, E.M. and Kaminarides, S.E. (1984) Changes in the microflora and the quality of Halloumi cheese kept in $10 \%$ brine at $4^{\circ} \mathrm{C}$ and $20^{\circ} \mathrm{C}$. Greek Dairy Federation Bulletin, I (3), 5- 15.

Anifantakis, E.M. and Kaminarides, S.E. (1982) Contribution to the study of Halloumi cheese made from cow's milk. Journal of Agricultural Research, 6, 119- 127 .
A.O.A.C. (2000) Associaction of Official Agriculture Chemists. "Official Methods of Analysis", 17 $7^{\text {th }}$ ed., Washington DC, USA.

Awad, R.A., Abdel-Hamid, L.B., El-Shabrawy, S.A. and Singh, R.K. (2002) Texture and microstructure of block type processed cheese with formulated emulsfying salt mixtures. LebensmittelWissenschaft und-Technologie, 351, 54- 61.

Awad, S. (2011) Texture and Microstructure. In 
Practical Food and Research. (Rui, M., Cru, S. (Ed.), pp.361-391, Nova Scinece publishers, Inc.,

Davies. G.J. (1970) "Cheese Manufacturing Methods" Vol. III Churchill Livingstone. London

Duncan, D. B. (1955) Multiple Range and Multiple F-Test. Biometrics, 11, 1-42.

Houghtby, G.A., Maturin L.J. and Koening, E.K. (1992) Microbiologi count methods In: Standard Methods for the Examination of Dairy Products, $16^{\text {th }}$ ed., R.T. Marshal (Ed). pp. 213-246. American Public Health Association, Washington, DC, USA.

Kaminarides, S., Rogoti, E. and Mallatou, H. (2000) Comparison of the characteristics of Halloumi cheese made from ovine milk, caprine milk or mixtures of these milks. Int. J. Dairy Technol. 53, 100-105.

Kosikowski, F.V. (1982) "Cheese and Fermented Milk Food" $2^{\text {nd }}$ ed., Brooktondale NY: F.V. Kosikowski and associated., pp. 384-412.

Lee, C.H., Imoto, E.M. and Rha, C. (1978) Evaluation of cheese texture. J. Food Sci., 43 (5), 1600-1605.

Lawson, P.A., Papademas. P., Wacher, C., Falsen, E., Robinson, R.K. and Collins, M.D. (2001) Lactobacillus cypricaseisp. nov., isolated from Halloumi cheese. International Journal of Systematic and Evolutionary Microbiology, 51, 45-59.

Mergim Mestani, Xhavit Ramadani, Tahire Maloku Gjergji, Hajrip Mehmeti, Arsim Ademi and Ibrahim Mehmeti (2017) The effect of saline concentration and storage temperature in the quality of
Sharri cheese. Journal of Food, Agriculture \& Environment, 15 (1), 12-17.

Milci, S., Goncu, A., Alpkent, Z. and Yaygın, H. (2005) Chemical, microbiological and sensory characterization of Halloumi cheese produced from ovine, caprine and bovine milk. International Dairy Journal, 15 (6- 9) ,625- 630.

Nelson, J.A. and Trout, G.M. (1981) “Judging of Dairy Products", $4^{\text {th }}$ ed. INC Westport, Academic Press, 345-567.

Nezhad, M.H. Duc., Han, N.F. and Hosseinian, F. (2013) Flaxseed soluble dietary fiber enhances Lactic acid bacterial survival and growth in kefir and possesses high antioxidant capacity. J. Food Res., 2, 152-163.

Panayiota Theophil, O.U. and Andrew wilbey, R. (2007) Effects of fat on the properties of Halloumi cheese. International Journal of Dairy Technology, 60, 1-4.

Photis, P. and Richard, K.R. (2000) A comparison of the chemical, microbiological and sensory characteristics of bovine and ovine Halloumi cheese. International Dairy Journal, 10, 761-768.

SAS (2004) SAS Institute Inc. SAS User's Guide, Statistics. Cary, NC.

Stelios, K., Ioannis, L., Theophilos, M. and Aikaterini, G. (2015) The effect of cooking time on curd compostion and textural properties of sheep Halloumi cheese. Small Ruminant Research, 125, 106-114. 
مقارنـة خصائص الجبن الحلوم المصنع من اللبن الماعز و اللبن البقزى وخليط منهما

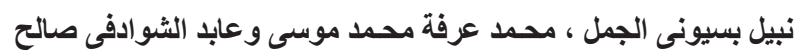

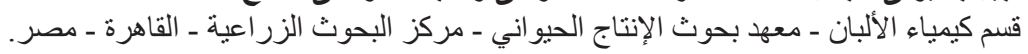

